\title{
Helppojen ajatusten takaa
}

Usein ajatellaan, että musiikissa on oleellista vain se, mikä soi,"itse musiikki”, ja että kaikki muu on "ulkomusiikillista" ja siten ylimääräistä, jopa turhaa. Yhtä helposti, ainakin länsimaisen taidemusiikin piirissä, voi lipsahtaa mieleen ajatus, että soivan musiikin alkuperäisin lähde on säveltäjän kynästä lähtenyt partituuri, jota esittäjien sitten tulee noudattaa enemmän tai vähemmän jämptisti.

Todellisuus on tietenkin monimutkaisempi. Säveltäjä saattaa korjailla teostaan jopa useaan otteeseen eri esityskertojen välillä. Lisäksi hän voi tehdä virheitä tai yksinkertaisesti muuttaa mieltään. Mikä on silloin alkuperäistä? Samankaltaisesti jokin ulkomusiikilliselta vaikuttava seikka, kuten muusikoiden keskinäinen elekommunikaatio esityksen aikana, saattaakin osoittautua välttämättömäksi, jotta esitys ylipäätään tulee mahdolliseksi ja "itse musiikki" voi soida.

Trion kesänumeron 2021 kaksi artikkelia käsittelevät näitä ilmiöitä.

Sasha Mäkilä tarkastelee partituurin painokuntoon saattamisen haasteita artikkelissaan "Kohti kriittistä editiota. Musiikkifilologinen analyysi Leevi Madetojan ensimmäisen sinfonian käsikirjoituslähteistä". Siinä hän muun muassa muodostaa valmistumisen historialliset sukupuut Madetojan sinfonian eri partituurilähteistä ja orkesteristemmoista käyttäen genealogista menetelmää ja tukeutuen biografiseen informaatioon (Grier 1996).

Sinfonian painettu partituuri julkaistiin vuonna 1984, kauan Madetojan (18871947) kuoleman jälkeen. Julkaistu partituuri perustuu säveltäjän itsensä alkuperäisestä käsikirjoituksesta kopioimaan ja korjaamaan uuteen käsikirjoitukseen, joka on Mäkilän päättelyn perusteella tehty vuonna 1943, yli neljännesvuosisata teoksen valmistumisen ja kantaesityksen (1916) jälkeen. Säveltäjän terveys ja muisti olivat kuitenkin tuolloin, neljä vuotta ennen kuolemaa, jo heikentyneet, eikä lähiluku korjauksineen tuottanut virheetöntä ja kaikilta osin loogista tulosta. Vaikka uuden käsikirjoituksen ulkoasu onkin siisti - alkuperäinen käsikirjoitus näet sisältää lukuisia oikaisuja ja muutoksia sekä esittäjien tekemiä merkintöjä - se on täynnä virheitä. Näitä virheitä on 1980-luvun puhtaaksikirjoittaja ilmeisesti pyrkinyt korjaamaan alkuperäisen käsikirjoituksen avulla. Tästä on seurannut lähteiden sekoittuminen eli kontaminaatio, minkä johdosta 1984 painettu partituuri ei täytä modernin kriittisen edition vaatimuksia.

Kriittisen edition toimittajalle avautuu ainakin kaksi vaihtoehtoista mahdollisuutta. Voidaan pyrkiä saattamaan teos mahdollisimman lähelle säveltäjän "viimeis- 
tä tahtoa" huomioiden kaikki mahdolliset korjaukset. Tämä tarkoittaisi viimeisen käsikirjoituksen virheiden ja epäloogisuuksien korjaamista aiempaan lähdemateriaaliin tukeutuen, mukaan luettuna eri tavoin korjatut orkesteristemmat. Toinen vaihtoehto on pyrkiä lähelle alkuperäistä versiota, mahdollisesti 1920-luvun taitteen esitysten yhteydessä tehtyjen ennen kustantamista tapahtuneiden "alkuperäisten" muutosten kanssa. Kyseessä on "lain kirjaimen ja hengen" välinen neuvottelu: pitäydytäänkö säveltäjän viimeisessä omakätisessä käsikirjoituksessa monine puutteineen vai pyritäänkö kaikki lähteet yhdistämällä kokoamaan musiikillisesti yhtenäinen säveltäjän tyylille uskollinen hybridiversio? Mäkilän artikkelissa kuvattu eri käsikirjoitusten välisten suhteiden ja valmistumishistorian selvitys antanee molemmille vaihtoehdoille hyvät lähtökohdat.

Maria Puusaaren artikkeli "Leading' as a mode of interaction and communication in contemporary music performance-practice" tarjoaa kokonaisvaltaisen esityksen nykymusiikin liidauksen eri tavoista, rooleista ja näihin vaikuttavista tekijöistä. Samalla se artikuloi kiinnostavalla tavalla musiikillisen liikehdinnän lähtökohtia ja hienovaraisia merkityksiä osana musiikillisen merkitystuotannon ydintä. Soittajan on suoriutuakseen yhteissoitollisesti vaativasta teoksesta hyödynnettävä kuulon lisäksi myös näköaistia ja liikkeen tuomaa visuaalista informaatiota "nuotin katsomisen" lisäksi. Toisaalta kun normaalisti liidausliikkeet on mahdollista suorittaa pelkkien soittamisliikkeiden päälle, teknisesti vaikeissa kohdissa liidaustehtävää pitää vuorotella, jos se osoittautuu pääliiderille soittoteknisten haasteiden vuoksi mahdottomaksi.

Yhteissoitollisten ja rytmisten haasteiden helpottamisen lisäksi liidauseleillä ilmaistaan myös tulkinnallisia asioita. Liikkeet voivat olla tarkasti suunniteltuja, mutta Puusaari huomasi harjoitteluvideoita analysoidessaan myös aiemmin itselleen tiedostamattomia liikkeitä. Esimerkiksi artikulaatiota, sointia ja intensiteettiä voi yhtenäistää ja synkronisoida paitsi kuuntelemalla myös seuraamalla muiden soittajien jousten liikettä. Tällöin liikkeen näkeminen toimii referenssinä kuulohavainnolle.

Puusaaren tutkimus rikastaa aistien integraatiota käsittelevän musiikintutkimuksen (Platz \& Kopiez, 2012; Russo, 2019) näkökulmia ja johtaa pohtimaan, mitä menetetään, mikäli ulkomusiikillisten seikkojen vaikutus musiikkikokemukseen kiistetään tai sitä vähätellään (ks. esim. McPherson \& Thompson 1998). Tutkimuksissa on todettu, että erityisesti jäädessään tiedostamattomaksi näköhavainto vaikuttaa suuresti niin kutsuttuun "puhtaaseen" musiikilliseen laatuarvioon (Tsay 2013).

Lopulta voimmekin ajatella positiivisesti Bergeronin ja Lopesin (2009) tavoin moniaistisuuden pikemminkin lisäävän musiikin arvoa ja merkityksiä kuin vähentävän tai vääristävän niitä:

Mikäli musiikki ilmaisee sitä, mitä ajattelemme sen ilmaisevan, sen ilmaisullinen voima näyttäisi olevan sekä visuaalinen että auditiivinen; mikäli musiikin ilmaisu- 
kyky sen sijaan pohjautuu ainoastaan äänellisiin ominaisuuksiin, sen kyky ilmaista ei ole niin suuri kuin ajattelemme sen olevan. Mikäli musiikki siis ilmaisee sekä auditiivisia että visuaalisia seikkoja, se ei ole sitä, mitä me ajattelemme sen olevan: se ei ole pelkästään auditiivinen ilmiö. ${ }^{1}$ (Bergeron \& Lopes 2009, 1.)

Musiikki voi siis pikemminkin olla sekä-että kuin joko-tai: erottelu "musiikilliseen" ja "ulkomusiikilliseen" ei tee oikeutta todellisuuden moninaisuudelle - oli sitten kyseessä muusikon eleiden välittämä kokemuksellisuus tai "säveltäjän tahdon" toteutuminen nuottikuvassa.

\section{Ulla Pohjannoro}

\section{LÄHTEET}

Bergeron, V. \& Lopes, D. M. 2009. Hearing and Seeing Musical Expression. Philosophy and Phenomenological Research, 78(1), 1-16. https://doi.org/10.1111/j.1933-1592.2008.00230.x

Grier, J. 1996. The critical editing of music: History, method, and practice. Cambridge University Press.

McPherson,G.E.\&Thompson,W.F.1998.AssessingMusic Performance:Issues and Influences. Research Studies in Music Education, 10(1), 12-24.https://doi.org/10.1177/1321103X9801000102

Platz, F. \& Kopiez, R. 2012. When the Eye Listens: A Meta-analysis of How Audio-visual Presentation Enhances the Appreciation of Music Performance. Music Perception, 30(1), 71-83.

Russo, F. 2019. Multisensory processing in music. Teoksessa D. A. Hodges, Donald \& Thaut, Michael (toim.) The Oxford handbook of music and the brain. New York, NY: Oxford University Press. 212-234.

Tsay, C.-J. 2013. Sight over sound in the judgment of music performance. Proceedings of the National Academy of Sciences, 110(36), 14580-14585. https://doi.org/10.1073/pnas.1221454110

1 If music expresses what we think it does, then its expressive properties may be visual as well as sonic; and if its expressive properties are purely sonic, then music expresses less than we think it does. And if the expressive properties of music are visual as well as sonic, then music is not what we think it is - it is not purely sonic. (Bergeron \& Lopes, 2009, 1.) 